\title{
Metode Pembentukan Karakter Religius Peserta Didik Program Full Day School di MI Terpadu Logaritma
}

\author{
Arni Ambarwati ${ }^{1}$, Suhartono², Ratna Hidayah ${ }^{3}$ \\ 1,2,3Universitas Sebelas Maret \\ arniambar25@gmail.com
}

\section{Article History}

accepted 01/02/2020

approved 01/03/2020

published 01/04/2020

\begin{abstract}
This study aims to describe the religious character building to students of full day school program in MI Terpadu Logaritma. The research uses qualitative method with case study approach. The data collection techniques include observation, interviews, and questionnaires. Data analysis uses qualitative data according to Miles and Huberman including data reduction, data presentation, and verification. The result shows that all methods of religious character building including examples of great people, story telling, advices, habituation, punishment and rewards, lectures, and discussions have applied. Giving advices and story telling are the most applied method for religious character building to students in MI Terpadu Logaritma. It concludes that religious character building to students of full day school program in MI Terpadu Logaritma are running well.
\end{abstract}

Keywords: Method, Religious Character Building, Full Day School

\section{Abstrak}

Penelitian ini bertujuan untuk mendeskripsikan metode pembentukan karakter religius peserta didik program full day school di MI Terpadu Logaritma. Penelitian ini menggunakan metode kualitatif dengan pendekatan studi kasus. Pengumpulan data dilaksanakan dengan teknik observasi, wawancara, dan angket. Analisis data menggunakan model analisis data kualitatif menurut Miles dan Huberman yang meliputi reduksi data, penyajian data, dan verifikasi. Hasil penelitian menunjukkan semua aspek metode pembentukan karakter religius yang meliputi: teladan, kisah, nasihat, pembiasaan, hukuman dan ganjaran, ceramah, dan diskusi sudah dilakukan sekolah. Metode yang ditekankan dan sering dilakukan dalam pembentukan karakter religius peserta didik di MI Terpadu Logaritma yaitu metode nasihat dan metode kisah. Kesimpulan yang diperoleh dari hasil penelitian tersebut yaitu metode pembentukan karakter religius peserta didik program full day school di MI Terpadu Logaritma yang sudah berjalan baik dengan metode nasihat dan kisah.

Kata kunci: Metode, Pembentukkan, Karakter Religius, Full Day School 


\section{PENDAHULUAN}

Degradasi karakter yang terjadi pada bangsa Indonesia merupakan sebagian permasalahan yang harus dicari solusinya. Hal ini dapat diketahui melalui media masa maupun media elektronik serta dapat dilihat secara langsung perilaku penyimpangan yang dilakukan oleh pelajar. Komisi Nasional Perlindungan Anak (Komnas PA) mencatat sebanyak 2.008 kasus kriminalitas yang dilakukan peserta didik usia sekolah terjadi di awal tahun 2012. Jumlah itu meliputi berbagai jenis kejahatan seperti pencurian, tawuran, dan pelecehan seksual yang dilakukan peserta didik SD hingga SMA. Fenomena yang memprihatinkan tersebut merupakan akibat dari kurang terkontrolnya pergaulan peserta didik dari pihak sekolah maupun pihak keluarga (Wicaksono, 2017: 11).

Salah satu degradasi karakter yang terjadi di Indonesia yakni degradasi karakter religius yang ditandai dengan penyimpangan religiusitas yang dilakukan peserta didik. Bentuk dari penyimpangan tersebut dapat terlihat dari perliku peserta didik yang suka berbohong, berkata kotor, menyakiti teman, mencuri uang di kantin, mencuri buku di perpustakaan, mengganggu teman ketika pembelajaran berlangsung, tidak menghormati guru, tidak mengerjakan PR, melanggar peraturan sekolah, berkata kasar, dan jarang melaksanakan persembahyangan di sekolah (Setianingsih, 2018; Bintari, dkk., 2014). Hal tersebut menunjukkan masih rendahnya konsep diri dan konsep religiusitas dikalangan peserta didik.

Safitri (2018: 278) mendefinisikan karakter religius sebagai, "Noted that the implementation of character education in religious values occurred through attitudes and behaviors regarding the tendency to be obedient to the teaching of one's religion, tolerant of others and live harmoniously with other religions".

Berbagai upaya pembentukan karakter religius peserta didik telah banyak dilakukan. Pemerintah melalui Peraturan Menteri Pendidikan dan Kebudayaan Nomor 23 tahun 2017 menetapkan penerapan pendidikan program full day school atau program belajar seharian penuh di beberapa sekolah di Indonesia termasuk pada jenjang pendidikan sekolah dasar. Program full day school menerapkan konsep dasar kegiatan terpadu dan kurikulum terpadu sebagai salah satu upaya pembentukan karakter religius, akidah dan akhlak serta menanamkan nilai-nilai positif pada peserta didik (Utomo, 2017; Benawa, dkk., 2018).

Dalam pembentukan karakter religius, diperlukan metode yang tepat agar terimplikasi dengan baik pada diri peserta didik. Menurut Abudin Nata, Alquran menawarkan berbagai metode pendidikan untuk membentuk karakter religius, yaitu: (1) Metode Teladan, dilakukan melalui teladan langsung (mencontohkan keteladann diri sendiri) dan teladan tidak langsung (menceritakan pengalaman tokoh lain); (2) Metode Kisah, dilakukan melalui metode kisah qurani (kisah-kisah yang terdapat dalam Alquran) dan metode kisah nabawi (kisah riwayat nabi, amal saleh, bersyukur atas nikmat Alloh); (3) Metode Nasihat, dilakukan secara klasikal maupun individual; (4) Metode Pembiasaan, merupakan pembiasaan dalam hal peribadahan (berdoa, salat, sholawat, mengaji); (5) Metode Hukuman dan Ganjaran, dilakukan dengan memberi hukuman bagi yang melakukan pelanggaran dan memberi ganjaran bagi melakukan kebaikan, ketaatan atau berprestasi baik; (6) Metode Ceramah, dilakukan dengan menyampaikan atau mengajak orang lain mengikuti ajaran yang telah ditentukan; (7) Metode Diskusi, dapat dilakukan dengan peserta didik dalam pembelajaran, diskusi antar guru, diskusi dengan orang tua wali berkaitan dengan pembentukan karakter religius (Asy'ari, 2017: 199).

Tujuan penelitian ini yakni untuk mendeskripsikan metode pembentukan karakter religius peserta didik program full day school di MI Terpadu Logaritma. 


\section{METODE}

Penelitian ini dilaksanakan di kelas V dan kelas VI MI Terpadu Logaritma. Penelitian menggunakan metode kualitatif dengan pendekatan studi kasus. Jumlah subjek penelitian sebanyak 91 peserta didik. Penelitian dilaksanakan selama 1 bulan, mulai bulan November hingga bulan Desember 2019. Sumber data penelitian ini yakni kepala MI, peserta didik kelas $\mathrm{V}$ dan kelas VI, guru kelas V dan kelas VI. Teknik pengumpulan data menggunakan teknik observasi, wawancara, dan angket skala Likert. Untuk menjamin kredibilitas data dalam penelitian ini dilakukan dengan triangulasi sumber dan teknik. Analisis data yang digunakan yakni analisis deskriptif untuk mendeskripsikan pembentukan karakter religius peserta didik program full day school.

\section{HASIL DAN PEMBAHASAN \\ Metode Pembentukan Karakter Religius Peserta Didik Program Full Day School}

1) Metode Teladan

Metode teladan menurut Abudin Nata (Asy'ari, 2017: 199) dilakukan dengan memberi teladan secara langsung dan teladan tidak langsung. Teladan langsung diberikan guru kepada peserta didik dengan menceritakan pengalaman dan kebaikan diri atau guru lain dengan tujuan meningkatkan motivasi peserta didik untuk berbuat kebaikan sesuai dengan yang dicontohkan. Selain dilakukan ketika muqodimah dan dalam mata pelajaran keagamaan, guru dan peserta didik senang berbagi pengalaman mereka dan saling bertukar cerita pada jam istirahat. Dengan kegiatan tersebut, dapat menambah wawasan peserta didik melalui cerita-cerita yang disampaikan guru dan peserta didik lain, sehingga mereka akan termotivasi dan menirunya. Teladan tidak langsung (menceritakan tokoh lain) dilaksanakan ketika muqodimah dan pada mata pelajaran keagamaan, seperti PAI, Alquran Hadis, Aqidah, dan Fiqih.

2) Metode Kisah

Metode kisah menurut Abudin Nata (Asy'ari, 2017: 199) dilakukan dengan memberi kisah qurani dan nabawi. Penerapan metode kisah di MI terpadu Logaritma dilakukan dengan cara menceritakan kisah dalam Alquran, Hadis, dan cerita tentang sahabat Nabi. Metode ini diberikan ketika guru memberikan muqodimah, mengaitkan pada pembelajaran, dan ketika memberi nasihat dengan tujuan agar peserta didik dapat menghayati dan meniru nilai-nilai yang terkadung dalam cerita. Hal tersebut sejalan dengan pendapat Harahap (2018: 16) yang menyatakan bahwa metode kisah merupakan metode yang menampilkan cerita sejarah faktual tentang kehidupan manusia yang dimaksudkan agar kehidupan manusia bisa seperti pelaku yang ditampilkan oleh kisah-kisah yang terdapat di dalam sumber pendidikan Islam itu sendiri.

Peserta didik sangat antusias ketika mendengarkan cerita Qurani, Hadis, termasuk juga cerita Sahabat Nabi yang diberikan guru. Selain itu, penerapan metode kisah dilaksanakan secara tidak langsung dengan menyediakan fasilitas buku-buku cerita Islami, seperti penyediaan buku-buku cerita tentang Nabi di pojok baca ruang kelas. Peserta didik terlihat sangat senang dan menghayati ketika membaca buku-buku tersebut.

3) Metode Nasihat

Penerapan metode nasihat dilaksanakan sesuai dengan pendapat Abudin Nata (Asy'ari, 2017: 199), yakni dilakukan secara klasikal dan individual. Nasihat dilakukan baik sebelum maupun sesudah terjadi pelanggaran yang dilakukan peserta didik. Nasihat sebelum terjadi pelanggaran bertujuan untuk mencegah tindakan menyimpang peserta didik. Nasihat setelah terjadi pelanggaran bertujuan agar peserta didik tidak mengulangi lagi pelanggaran yang tekah dilakukan. Nasihat dapat dilakukan guru mata pelajaran, guru wali kelas, dan kepala MI. 
Nasihat klasikal dilakukan baik sebelum maupun sesudah terjadi pelanggaran dilakukan peserta didik. Sementara itu, nasihat individual dilakukan jika ada satu peserta didik yang melakukan hal yang tidak baik. Peserta didik tersebut akan dinasihati oleh guru. Hal tersebut sejalan dengan pendapat Harahap (2018: 16) yang menyatakan bahwa nasihat pada dasarnya bersifat penyampain pesan dari sumbernya kepada pihak yang dipandang memerlukannya. Jika peserta didik mengulanginya sampai empat kali, maka kepala MI yang akan menanganinya. Kepala MI juga memanggil orang tua peserta didik tersebut untuk mendiskusikan solusi terbaik yang akan diberikan.

4) Metode Pembiasaan

Penerapan metode pembiasaan yang dilaksanakan sesuai dengan pendapat Abudin Nata (Asy'ari, 2017: 199), yakni dengan melakukan pembiasaan dalam peribadahan seperti murojaah, salat duha, salat zuhur dan asar berjamaah, makan bersama, qailullah, berpakaian sesuai ketentuan Islam, dan mengucapkan salam ketika masuk ruangan. Selain itu, pembiasaan-pembiasaan baik yang berlaku di MI Terpadu Logaritma yakni pembiasaan berupa adab bermain di luar kelas, adab di luar kelas, adab bergaul dengan teman, adab makan, adab dalam kamar mandi, adab bergaul dengan ustaz/ustazah.

Pembiasaan yang diterapkan MI Terpasu Logaritma dilakukan secara bertahap dan berulang untuk merubah perilaku buruk peserta didik. Hal tersebut sejalan dengan pendapat Harahap (2018: 17) yang menyatakan bahwa inti pembiasaan adalah pengulangan yang berusaha merubah kebiasaan-kebiasaan yang negatif peserta didik. Metode pembiasaan yang dilaksanakan MI Terpadu Logaritma bertujuan untuk menumbuhkan kesadaran pada peserta didik, sehingga mereka akan melakukan kebaikakan tanpa merasa keberatan dan berpikir panjang karena sudah dilakuakan secara berulang-ulang dan terus-menerus. Hal tersebut sesuai dengan pendapat Nawali (2018: 115) yang menyatakan bahwa pembiasaan dapat mendorong mempercepat perilaku, dan tanpa pembiasaan hidup seseorang akan berjalan lamban, sebab sebelum melakukan sesuatu harus memikirkan terlebih dahulu apa yang akan dilakukannya.

5) Metode Hukuman dan Ganjaran

Sesuai dengan pendapat Abudin Nata (Asy'ari, 2017: 199), penerapan metode hukuman dan ganjaran di MI Terpadu Logaritma dilakukan dengan memberikan amal soleh kepada peserta didik yang melakukan pelanggaran dan memberikan hadiah kepada peserta didik yang berbuat kebaikan. Amal soleh dilakukan dengan memberi hukuman yang mendidik peserta didik, seperti membersihkan kamar mandi, membersihkan musala, infak, dan menghafal Alquran. Sementara itu, terdapat juga pada perjanjian yang dilakukan guru dengan peserta didik dilakukan di awal semester ganjil. Perjanjian tersebut dibuat dan disesuakian dengan kebutuhan masing-masing kelas. Hukuman yang terdapat di perjainjian kelas, yakni: pemindahan tempat duduk jika ribut dalam pembelajaran, piala reward hafalan akan ditarik jika sering tidak murojaah, dan membersihkan ruang kelas. Pemberian hukuman secara tepat dan bijak bisa menjadi alat motivasi bagi peserta didik, sehingga peserta didik bisa memahami makna hukuman yang didapat dan peserta didik tidak akan mengulang pelanggaran lagi (Sardiman, 2011: 94).

Hukuman dilakukan jika peserta didik mengulang kesalahan setelah diberi nasihat, karena sekolah tidak akan langsung memberi hukuman kepada peserta didik melainkan dengan memberi nasihat terlebih dahulu ketika melakukan perbuatan yang tidak baik. Hal tersebut sejalan dengan pendapat Harahap (2018: 17) yang menyatakan bahawa hukuman bukan sebagai tindakan yang pertama kali dan yang didahulukan yang harus dilakukan oleh guru, melainkan nasihatlah yang paling didahulukan. 
Sementara itu, pemberian hadiah dilakukan dengan memberi barang seperti buku dan bolpon. Hadiah tersebut diberikan ketika peserta didik dapat menjawab pertanyaan atau mendapat nilai yang baik. Pemberian hadiah tidak dilakukan terus menerus, hal tersebut dilakukan agar peserta didik iklas ketika berbuat kebaikan dan tidak mengharap imbalan. Sementara itu, bagi peserta didik yang lulus dan menyeleseaikan hafalan Alquran akan diberi hadian berupa piala penghargaan. Selain dalam bentuk hadiah barang, guru juga akan memberi pujian bagi peserta didik yang melakukan kebaikan. Pujian akan menumbuhkan moitvasi peserta didik, sehingga peserta didik akan termotivasi mengulang perbuatan baik tersebut. Hal tersebut sejalan dengan pendapat Sardiman (2011:94) yang menyatakan bahwa pujian merupakan reinforcement yang positif dan sekaligus merupakan motivasi yang baik bagi peserta didik.

6) Metode Ceramah

Penerapan metode cearmahan tentang nilai-nilai religius diberikan dengan memberikan suatu cerita atau kisah. Pemberian cermaha dilakukan di pagi hari ketika muqodimah, dalam pembelajaran, ketika evaluasi, dan kajian setelah salat yang dilakukan oleh imam salat. Hal tersebut sejalan dengan pendapat Harahap (2018: 17) yang menyatakan bahwa metode ceramah menggabungkan metode ceramah dengan metode cerita karena kebiasaan bercerita akan diungkapkan melalui ceramah oleh guru. Metode ceramah merupakan metode yang sering dilakukan oleh guru karena metode ceramah merupakan metode yang mudah dilakukan, tidak memerlukan biaya banyak, materi dapat ditentukan dahulu sebelum ceramah.

Pemberian ceramah yang dilakukan dapat menambah pengetahuan baru pada peserta didik. Pengetahuan-pengetahuan baru yang didapatkan dapat dijadikan sebagai pedoman untuk melaksanakan kebaikan. Hal tersebut sejalan dengan pendapat Abudin Nata (Asy'ari, 2017: 199) yang menyatakan bahwa pemberian cermah bertujuan agar peserta didik mendapat pengetahuan baru dan dapat melaksanakan ajaran yang disampaikan dalam ceramah.

7) Metode Diskusi

Penerapan metode diskusi berdasarkan pendapat Abudin Nata (Asy'ari, 2017: 199), yakni dengan berdiskusi dengan peserta didik, diskusi antar guru, dan diskusi dengan orang tua wali. Penerapan metode diskuis di MI terpadu Logaritma diantaranya dilakukan dengan berdiskusi dengan peserta didik, yaitu diskusi berkaitan dengan memaknai kandungan Alquran yang dilakukan pada saat pembelajaran maupun di luar pembelajaran.

Diskusi dengan sesama guru dilakukan ketika rapat, muhasabah, evaluasi, dan muqodimah yang dipimpin oleh kepala MI. Diskusi tersebut dilakukan untuk membuat rencana kegiatan yang mendukung pembentukan karakter religius peserta didik, mengevaluai kegiatan dan perilaku guru yang tidak sesuai dengan ketentuan sehingga menjadi contoh yang tidak baik bagi peserta didik, dan diskusi mencari alternatif solusi untuk kegiatan yang tidak berjalan dengan baik.

Sementara itu, diskusi dengan orang tua wali dilakukan ketika paguyuban, parenting, ketika pengambilan rapor dan melalui pesan singkat untuk memantau perilaku dan kegiatan peserta didik di rumah. Diskusi yang dilakukan yakni mendiskusikan tentang bagaimana mendidik peserta didik di rumah, mendiskusikan permasalahan kehadiran, kepribadian, dan akhlak, serta mendiskusikan permasalahan akademik peserta didik

Diskusi yang dilakukan sekolah diharapkan dapat menyelesaikan permasalahan yang ada. Hal tersebut sejalan dengan pendapat Harahap (2018: 18) yang menyatakan bahwa diskusi bertujuan untuk membicarakan dan menganalisis secara ilmiah guna mengumpulkan pendapat, membuat kesimpulan atau menyusun berbagai alternatif pemecahan atas suatu masalah. 
Metode yang ditenkan di MI Terpadu Logaritma yakni metode nasihat dan metode kisah. Metode nasihat dan metode kisah merupakan metode yang mudah dilakukan karena dapat diaplikasikan atau disampaikan bersamaan dengan metode lainnya. Pemberian nasihat dilakukan secara berulang-ulang oleh guru, baik sebelum maupun sesudah terjadi pelanggaran. Sementara itu, metode kisah dapat dilakukan secara langsung maupun tidak langsung dengan menyediakan buku-buku kisah Nabi di sekolah.

\section{SIMPULAN}

Berdasarkan penelitian dan pembahasan yang telah diuraikan, dapat disimpulkan bahwa metode pembentukan karakter religius peserta didik program full day school di MI Terpadu Logaritma dilaksanakan dengan baik. Hal tersebut dapat diketahui dari semua aspek metode pembentukan karakter religius yang meliputi: teladan, kisah, nasihat, pembiasaan, hukuman dan ganjaran, ceramah, diskusi sudah dilaksanakan sekolah. Metode yang ditekankan dan sering dilakukan dalam pembentukan karakter religius peserta didik di MI Terpadu Logaritma yaitu metode nasihat dan metode kisah. Dari hasil temuan dan analisis penelitian, ada beberapa hal yang dapat dijadikan sebagai saran atau masukan, yaitu bagi peneliti yang akan meneliti metode pembentukan karakter religius peserta didik program full day school, penelitian ini dapat dijadikan sebagai acuan atau referensi untuk membantu dalam melakukan penelitian. Selain itu, diharapkan peneliti lain dapat mengembangkan penelitian dengan membahas lebih mendalam lagi setiap indikator yang dapat dijadikan tolok ukur keberhasilan.

\section{DAFTAR PUSTAKA}

Asy’ari, M.K. (2017). Metode Pendidikan Islam. Qathruna, 1(01). 193-205.

Bintari, N. P., Dantes, N., \& Made Sulastri, M. P. (2014). Korelasi konsep diri dan sikap religiusitas terhadap kecenderungan perilaku menyimpang dikalangan siswa pada kelas XI SMA Negeri 4 Singaraja tahun ajaran 2013/2014. Jurnal Ilmiah Bimbingan Konseling Undiksha, 2(1).

Benawa, A., Peter, R., \& Makmun. (2018). The Effectiveness of Full day School System for Students' Character Building. In IOP Converence Series: Materials Science and Engineering 288(1).

Harahap, A. S. (2018). Metode Pendidikan Islam Dalam Perspektif Filsafat Pendidikan Islam. Hikmah, 15(1), 8.

Nawali, A. K. (2018). Hakikat, Nilai-Nilai dan Strategi Pembentukan Karakter (Akhlak) dalam Islam. Jurnal Studi Pendidikan Islam, 1(2).

Safitri, D. D. (2018). Managing School Based on Character Building in The Context of Religious School Culture (Case in Indonesia). Journal of Social Studies Education Research, 9(4), 274-294.

Sardiman. (2011). Interaksi \& Motivasi Belajar Mengajar. Jakarta: Rajawali Pers.

Setianingsih, A. (2018). Internalisasi Karakter Religius di SD Negeri Demakijo 1. Basic Education, 7(1), 1-12. 
Volume 8 Nomor 1 Tahun 2019

Utomo, T. P. (2017). Meningkatkan Prestasi Peserta Didik Melalui Pendidikan Full Day School. Al-Asasiyya: Journal Of Basic Education, 1(1).

Wicaksono, A. G. (2017). Fenomena Full Day School dalam Sistem Pendidikan Indonesia. Jurnal Komunikasi Pendidikan, 1(1), 10-18. 